fatal whatever might be done. I wish no one to be mistaken as to the class of cases about which I am talking. There is a vast difference in the chances of a woman taken with eclampsia when labor is present or has progressed more or less, and the chances of one taken with eclampsia in the eighth or ninth month of pregnancy all signs of labor being absent. It is of this latter class that I am spenking. All of these three women were in extremis and I am sure that with any other mode of anesthesia they would have been lost.

'There was much doubt in my mind, before doing my lirst operation, as to whether or not the uterus would contract promptly and efficiently under this form of anesthesia, but in all of the cases the contraction was exeellent and just as firm as when I liave done cesalean section under ether.

Professor Babcock of Philadelplin writes me that he is quite sure that these cesarean sections are the first. in the United States to lave been done under spinal ancsthesia ; he thinks that they are the first to he reported l'om any cotuntly'.

18.88 lifth Avenue.

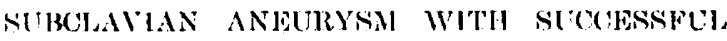 ENDO.ANIAURYSMORIRHAWHY}

Gamie Drennen, M.D., Bhimingham, Ai.h.

l'aticnt.-1R. W., a boiler-maker, aged 38, whs admitted to Ni. Vincent's Hospitul Mu'ch 12, 1012. He whs pulseless and in extreme shock from loss of blood consequent on a stal wound just henenth the middle of the left claviele, inflicted n few minntes before. By packing the round and applying presisure ov'(1) it, hemorrhage was checked. The shock was comluted by intruvenous infusion and other routine mensures. Jour duys later, signs of aneurym were first discovered on nuscentating near the stab wound, which region was perecptibly bulging. Expansile pulsation and a thrill were evident, to palpation. 'l'he left radinl pulse was slighly wenker than that of the right sisle. He wis. kept in led with rest and suituble diet for three weeks. During this time, he complained of considerable pain over the tumor and shooting down the um. Beginning on the eighth day, powerful compression was applied over abd just ubove the tumor three times daily, for " period of fifteen mimutes eath time. The pressure employed ubove the daviele stilled the pulsation and bruit in the sate; likewise the radial pulse was ohlitornted. Following this procedure, the patient experienced complete rolief from his pain. At the end of three weeks he refused operation, and left the hospitul. Two weeks later he returned, complaining of much pnin over the tumor, whicli had risibly incrensed in size. He was pule and very wenk. Operation was decided on at once. His family and pust history were negative. He had never had syphilis.

Operation.--The putient was anesthetized and an incision 3 inches in length was made about half an inch above the elavicle and parallel to it. The subelavian artery was exposed und a temporary thpe ligature passed nround it and tied at the point where the artery omerged from behind the sealenus nuticus musele. Next an incision 4 inches in length was made ulong the lower horder of the chavicle, its middlo corresponding to the bulging of the tumor. The sue was quickly oponed and furious hemonlhage oceured. This was controlled with grent difliculty by pressure, but in spite of all efforts blood kept welling up in such quantities that nothing eould be done. Finally an nneurysm neodle, threaded with " stout, henvy lignture, was passed around the artery, benenth the chuvicle just proximul to the suc, the wounds above and below the clavicle having been made freely into one large wound. Jy a lifting and squeezing action with this ligature, all hemorrhage from the proximal opening into the sac was stopped. The blecding from the distal opening was controlled by pressure,
Hud a stitch taken abross its lumen; when pulled on, this stitch ellectunlly stopped all bleeding. It could now be seen that the aneurym involved the third portion of the left subclavian artery, that it was the rize of a small hen's egg and contained considernble filorin, clots, ete., and that there were two openings about three-eighth of an inch in dianeter, and " similar distance npart. No groove between the two could be demonstrated. The detritus was removed from the sac. The openings were then closed with interrupted chromic entgut stitches, four stitches being taken in the lower, and five in the upper. The temporary ligatures proximal to the sne were now removed; the sac remained dry. The sae was then elosed with a rumuing lembert suture. The radinl pulse, while quite wenk on the left ride, immodiately after the operation, was easily felt, and the next day was equni in size and strength to that of its fellow.

Postoporative History.-Herling ocenred by first intention, and convalescence was uncyentful. The patient was kept in bed thres weoks and then sllowed to go about. Since the operation the left arm and side have beon normal in all resperts. The patient returned to his arduous work eiglit weeks after the operation. When he was seen three woeks later, here wis no timor, no bruit. and no pulsntion under the sicar. The left radial pulse was similar in all respects to that on the right side. The patient feels well, and has gained 25 pounds. Although cureful seureh has been made of the literature, no record of a sucesssful meurymorrhuphy of the subeluvian urtery has been fond. It is my belief that it was possible in this instance only bechuse all the tissues involved were healthy. The most impressive thing about the operation was that ligature, above the suc, apparently lad no effect on rhecking liemorrhage from the opened str. It is possible nlso that the compression employed in this cuse accentuated nn alrendy free colluternl circulation.

\section{A CASE OF SPOROTRICHOSIS IN NORTH DAKO'TA: PROBABLE INFECTION FROM GOPHERS}

\section{G. M. OISON, M.D., HARto, N. Dak.}

$\Lambda$ few rases of sporotrichosis linve been reported in North Dakota. Probably many cases are not recognized. Diugnosis is ensy if this discuse is kept in mind. Potassium iodid occasions a prompt recovery. Ordinary surgienl trentment is of little avail.

Patient-- (. A., a man, aged 19. Five weeks before examination, while at "Tappen, N. Dak., a lump like a "lonil" appeared on the dorsum of the right land. No prin, tenderness, fever or other constitutional symptoms were present. A few duys lnter subcutuneous nodules begun to appenr on the buck of the right forearm. On examimation there was an uler about 1 inch in diameter on the dorsum of the right hand. The uleer was raised and contained thick gelatinous pus. There was no pain, tenderness, fever or hendache. Three nodules on the back of the right forearm were similar to that on the land except that there was no ulceration. There was a distal nodule nbont one-lunf inch in dinmeter, raised and purple-red in color. Other nodules were smaller. Proximul nodules were wholly subcutaneous and not adherent to the wkin.

Culture-O) blood-serum a mumber of snowy white colonies appeared in three or four days. Two days later the colonies were brown. A smear from the culture showed a brunching mycelium with ovul or ovoid spores.

Source of In/ection.-Pntient was on $n$ furm at Tappen, $N$. Dak. but states that nome of the cows or horses had any sores. Many gophers that he killed and handled had sores similar to that which later appeared on his hand. $A$ s sporotrichosis is present among rats, it is probable that gophor's may be infected with this disease.

Treatment.-Tincture of iodin was applied locally and potas. sium ioclid, 10 minims, -was given three times a day. In ten days the ulcer had nearly lienled and the nodules had almost disapporated. 